\title{
Deciphering UN development policies: from the modernization paradigm to the human development approach?
}

Panayotis M. Protopsaltis*

Centre for American Legal Studies, Birmingham City University, U.K.

\section{Introduction}

Theoretical analysis on the causes of underdevelopment and the methods to achieve development produced a number of different paradigms. Schematically, to the original hegemonic modernization paradigm ${ }^{1}$ opposed the dependency theory ${ }^{2}$ the teachings of which were prominent during the $1970 \mathrm{~s}^{3}$ and influenced the demands for the establishment of a New International Economic Order (NIEO). ${ }^{4}$ Both paradigms were largely superseded in the $1990 \mathrm{~s}$ by the human development approach. ${ }^{5}$

The modernization paradigm and the dependency theory adopted a linear, progressive concept of development, conceiving the condition of developing countries with reference to the past of the developed ones, developing countries being at a prior stage in the process of their development. Both focused on economic development, identified with economic growth measured in terms of GDP, ${ }^{6}$ on the assumption that once this is achieved, all other aspects of development will follow. ${ }^{7}$ Albeit for different reasons, ${ }^{8}$ they both attributed a central role to State planning and intervention in the national economy for the achievement of development.

The modernization paradigm considered that the causes of underdevelopment were internal and could be cured by external assistance like technological aid and stressed the role of industrialization as the quickest means to cover the development gap of developing countries ${ }^{9}$ while paying little attention to human welfare or public goods. ${ }^{10}$ In contrast, according to the dependency theory, the causes of underdevelopment were mainly external, namely, the

\footnotetext{
* panayotis.protopsaltis@bcu.ac.uk

${ }^{1}$ Cf. Stokke, The UN and Development, 19, 316.

2 Rist, The History of Development, 113-118.

${ }^{3}$ Leys, "The Rise and Fall of Development Theory", 111-112; Stokke, The UN and Development, 132.

${ }^{4}$ Hettne, Development Theory, 103.

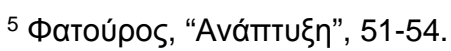

${ }^{6}$ Sachs, The Age of Sustainable Development, 14-23; Cf. Ziai, Development Discourse, 177.

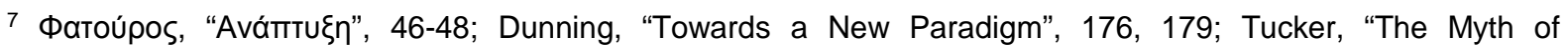
Development", 12.

8 The explanation is found in the neo-Keynesian origins of the modernization paradigm and in the neo-Marxian origins of the dependency theory [Cf. Leys, "The Rise and Fall of Development Theory", 111, 113].

9 Blömström \& Hettne, Development Theory, 20; Leys, "The Rise and Fall of Development Theory", 111-112; Cf. Tucker, "The Myth of Development", 2-3.

10 Cf. Dunning, "Towards a New Paradigm", 176.
} 
dependence of developing countries on the economically more developed ones. Development could then be achieved through the dissociation of developing nations from the world market, self-determination, self-reliance and import substitution. ${ }^{11}$

The post-1980s liberalization of the markets and the technological advances in trans-border communications resulting from changes in political and economic ideologies led to the rethinking of development and the birth of a new development model. ${ }^{12}$ The human development approach finds the causes of underdevelopment to be both internal and external. Ackowledgeing the absence of a universal development model leading to sustainability at all levels of the society and the world, it saw development as an integral, multidimensional process that includes social development and good governance, elimination of poverty and development of institutions, ${ }^{13}$ to be achieved with the mobilization of all stakeholders of the society. ${ }^{14}$ Economic growth, in contrast, is not a necessary component of the human development approach. ${ }^{15}$

It was against this theoretical background that the discussions on development evolved in the UN and other international fora since World War II. The UN gradually established the UN Development System, an institutional framework for the support of developing countries, ${ }^{16}$ and designed special programs for the achievement of concrete goals of development. These programs incorporated the views of the UN Secretary General and the influential developed countries donating Official Development Assistance (ODA), particularly the United States, ${ }^{17}$ as well as the evolution of development economics, ${ }^{18}$ while responding to the ever-changing international economic and political circumstances. ${ }^{19}$ Stokke distinguishes between two periods in the evolution of these programs. The first includes programs adopted from the end of 1940 to the end of 1970 whereas the second begun with the programs inaugurated after the 'lost decade' of 1980, from the 1990s up until today. ${ }^{20}$

\footnotetext{
11 Фaтоúpos, "Avátттu६n", 48-49; Blömström \& Hettne, Development Theory, 56-78; Leys, "The Rise and Fall of Development Theory", 112-114, Stokke, The UN and Development, 132-133.

12 Dunning, "Towards a New Paradigm", 180.

${ }^{13}$ E.g. Acemoglu \& Robinson, Why Nations Fail.

14 Dunning, "Towards a New Paradigm”, 183-199.

15 Ziai, Development Discourse, 174.

${ }_{16}$ Murphy, "Evolution of the UN Development System", 35-54; Browne, "United Nations Development System in Asia".

17 On the role of the United States and the use of ODA as a tool of foreign policy, see, Rist, The History of Development, 70-72; Stokke, The UN and Development, 48-50, 309-310.

18 Cf. Фaтoúpos, "Avámtu६n”, 39.

${ }^{19}$ Stokke, The UN and Development, 134.

20 Ibid., 132-133, 316-330; Cf. Brenner, "Global Goal-Setting”, 151-152.
} 
The General Assembly resolutions on the UN Development Decades (DDs) establish a general policy framework to guide international action and national development policies. Their comparative analysis of reveals the standardization of the UN programs. All resolutions contain an introduction on general principles, define the goals and objectives of development, determine quantitative input (resources for financing development) and output (economic growth and social welfare) targets and recommend policy measures for their achievement.

Despite the use of standardized phraseology, ${ }^{21}$ common to most UN resolutions, the changes in their goals and objectives, targets and policy measures reveal an evolution of the UN policies, a gradual shift from the economic goals of the modernization paradigm to the welfare goals of the human development approach, even though the goal of economic growth was never entirely abandoned. Nevertheless, all resolutions adopt an identical method for the achievement of development. They all set quantitative targets on inputs and outputs to be met through recommended measures involving State intervention in the economy and society introduced into developing countries' development plans, in accordance with the teachings of the modernization paradigm.

\section{The evolution of the UN development policies}

Even though all relevant resolutions mention both economic and social development without always defining a relation of priority, the comparative analysis of their narratives reveals a gradual shift in focus. Jolly claims that "[o]ver the years, the UN'S vision of development shifted, moving from the narrowly economic to the broader, multidisciplinary perspective by the 1990s". ${ }^{22}$ Subscribing to the modernization paradigm, the resolutions of the first three DDs focused on economic development, setting primarily economic goals accompanied by quantitative targets of economic growth. As Jolly, again, explains, "[t]he UN's initial focus on development as an economic process was in line with thinking about economic development at the time". ${ }^{23}$ However, the Strategies for the Second and Third DDs favored also regional cooperation, in line with dependency theory. In contrast, espousing the human development approach, the Strategy for the Fourth DD, the Millennium Declaration and the Agenda 2030 gradually expanded the existing and introduced new welfare goals along with relevant quantitative targets. After the interval of the Millennium Declaration, the UN re-introduced the economic goals in its development agenda, this time in the context of sustainable development. Yet, the remaining dimensions of sustainable development (social inclusion,

\footnotetext{
${ }^{21}$ E.g., Flory, "The International Development Strategy", 69.

22 Jolly, "The UN Development," 51.

23 lbid., 52.
} 
environmental sustainability and good governance) temper the aim of economic growth with elements of the human development approach. ${ }^{24}$

\section{A. The Modernization Paradigm in the Formative Years}

The Program for the First DD (1961) invited countries to mobilize and support "the measures required ... to accelerate the progress towards self-sustaining growth of the economy of the individual nations and their social advancement so as to attain ... a substantial increase of the rate of growth". ${ }^{25}$ The resolution defined a general framework of "approaches and measures designed to further the objectives" 26 and introduced a single quantitate target of economic growth. ${ }^{27}$ It recommended "[t]he achievement and acceleration of sound self-sustaining economic development ... through industrialisation, diversification and development of a highly productive agricultural sector". ${ }^{28}$ Independent references to social development were absent. The resolution mentioned only the improvement of "the use of international institutions and instrumentalities for furthering economic and social development", 29 "[t] of research' and 'other efforts to exploit scientific and technological potentialities for accelerating economic and social development", ${ }^{30}$ a locus classicus of the modernization paradigm, ${ }^{31}$ as well as the "utilisation of resources ... for the purpose of economic and social development". ${ }^{32}$ Social development was thus presented as complementary to economic development. Some measures relating to social welfare included the "elimination of illiteracy, hunger and disease, which seriously affect", that is, because they affect, "productivity of the people of the less developed countries". ${ }^{33}$ In other words, those measures were recommended in order to support of the goal of economic development. ${ }^{34}$

In the Strategy of the Second DD (1970) governments pledged themselves "to pursue policies designated to create a more just and rational world economic and social order". ${ }^{35}$ The

\footnotetext{
${ }^{24}$ Cf. Sachs, The Age of Sustainable Development, 1-44, 502-505.

25 UN Development Decade: A Programme for International Economic Co-operation (I), para. 1.

26 lbid., para. 4.

27 lbid., para. 1.

28 lbid., para. 4(a).

29 Ibid., para. 4(c).

30 Ibid., para. 4(f).

31 Stokke, The UN and Development, 144.

32 UN Development Decade: A Programme for International Economic Co-operation (I), para. 4(i).

33 Ibid., para. 4(d).

${ }^{34}$ Normand \& Zaidi, Human Rights at the UN, 295-296.

35 UN, International Development Strategy for the Second Development Decade, para. 12.
} 
resolution focused on economic development, ${ }^{36}$ setting economic goals and quantitative targets of economic growth. ${ }^{37}$ Despite its references to "improvement in the well-being of the individual" as "[t]he ultimate goal of development", ${ }^{38}$ the resolution attached social welfare to economic growth. ${ }^{39}$ Its chapter on goals explained the importance of "a more equitable distribution of income and wealth for promoting both social justice and efficiency of production, to raise substantially the level of employment, to achieve greater degree of income security, to expand and improve facilities for education, health, nutrition, housing and social welfare, and to safeguard the environment'. Stressing the complementary character of economic and social development, it added that "qualitative and structural changes in the society must go hand in hand with rapid economic growth, and existing disparities ... should be substantially reduced". The resolution enumerated a number of social welfare objectives (employment, education, health, nutrition, housing, well-being of children, and participation of the women in the development effort) as "both determining factors and end-results of development" to "be viewed as integrated parts of the same dynamic process and would require a unified approach". ${ }^{40}$ Yet, the policy measures recommended focused mainly on economic development. ${ }^{41}$ Amongst them, economic cooperation and regional integration, ${ }^{42}$ presumably introduced at the proposal of UNCTAD, ${ }^{43}$ echoed the dependency theory. Measures for social welfare were, in contrast, limited. But the introduction of a separate chapter on "human development' indicated that the UN recognized the need for special measures, not necessarily identical to those required for the achievement of economic development. The resolution recommended measures designed to assist economic development (echoing neo-Malthusian arguments amidst concerns over population growth, it referred to the control of population along with employment and education in order to increase productivity $)^{44}$ as well as measures aiming at the improvement of the conditions of life in developing countries (the establishment of health facilities, nutrition, children, youth policies and the improvement of housing and human environment). ${ }^{45}$

\footnotetext{
${ }^{36}$ Cf. Ziai, Development Discourse, 167.

${ }^{37}$ UN, International Development Strategy for the Second Development Decade, paras. 13-14.

${ }^{38} \mathrm{Ibid}$., para. 7.

${ }^{39}$ Contra, Normand \& Zaidi, Human Rights at the UN, 296.

${ }^{40}$ UN, International Development Strategy for the Second Development Decade, para. 18.

${ }^{41}$ Ibid., paras. 21-64.

42 Ibid., paras. 39-40.

${ }^{43}$ Stokke, The UN and Development, 170; Cf. Flory, "The International Development Strategy", 68.

${ }^{44}$ UN, International Development Strategy for the Second Development Decade, paras. 65-67.

45 Ibid., paras. 68-72.
} 
The Strategy for the Third DD (1980) extended the objectives and policy measures of the Strategy for the Second, incorporating the demands for a NIEO. ${ }^{46}$ Its preamble mentioned, amongst others, the "promotion of the economic and social development ... with a view to reducing significantly the current disparities between developed and developing countries, as well as the early eradication of poverty and dependence which, in turn contribute to the solution of international economic problems and sustained global economic development, and would also be supported by such development". ${ }^{47}$ Anticipating globalization, this circular argument posits that economic and social development of developing countries is a precondition for global economic development which, in turn, will support developing countries' economic and social development. The resolution mentioned also numerous aims supporting economic development like the employment and development of human resources with special focus on education, ${ }^{48}$ and set a number of targets for economic growth. ${ }^{49}$

Yet, the resolution repeated that "[t]he ultimate aim of development is the constant improvement of the well-being of the entire population on the basis of its full participation in the process of development and a fair distribution of the benefits therefrom". It recognized "economic growth, productive employment and social equity" as "fundamental and indivisible elements of development". ${ }^{50}$ Development was seen as an "integral process, embodying both economic and social objectives". Countries were invited to establish "adequate national objectives for the promotion of human and social development within the framework of its development plans". ${ }^{51}$ The objectives recommended included the elimination of poverty, the improvement of health and the provision of basic shelter and infrastructure for all people. ${ }^{52}$ However, the policy measures focused again on economic development. ${ }^{53}$ Amongst them, liberalization of trade and structural adjustment were mentioned for the first time ${ }^{54}$ while the cooperation among developing countries based on the principle of collective self-reliance that echoed the dependency theory was repeated. ${ }^{55}$ Measures relating to social welfare were, again, limited. A new chapter on environment referred to the promotion of "environmental and

\footnotetext{
46 UN, International Development Strategy for the Third Development Decade, para. 6, 17; Cf. Flory, "The International Development Strategy", 68.

47 UN, International Development Strategy for the Third Development Decade, para. 7.

48 lbid., paras. 44, 46.

49 lbid., paras. 20-23, 28-29.

50 lbid., para. 8.

51 lbid., para. 42.

52 Ibid., paras. 43, 48-49.

53 lbid., paras. 52-95, 115-155.

54 Ibid., paras. 22, 52, 60.

55 lbid., paras. 9, 40, 67, 134-135.
} 
ecological soundness of developmental activities" ${ }^{56}$ while a new chapter on human settlements focused on the improvement of the "quality of life and the environment". ${ }^{77}$ Finally, the chapter on "social development" included again measures assisting economic development (improvement of employment opportunities, education and control of population) and measures relating to the improvement of the conditions of life in developing countries (reduction of poverty, improvement of health and of women's status). ${ }^{58}$

Even though the promotion of social development has always been part of the UN rhetoric, the recommended policy measures focused primarily on economic development and quantifiable targets were set only in relation to economic growth. ${ }^{59}$ The introduction of a chapter on human development in the Strategy for the Second DD, subsequently renamed social development in the Strategy for the Third, should not necessarily be interpreted as a departure from the modernization paradigm. Social development was still seen as the necessary outcome of economic growth and social welfare was actively promoted less as an independent value and more because - and to the extent that - it was necessary for the achievement of economic development. Measures for the improvement of the quality of life were introduced on the assumption that poor living and health conditions affected productivity therefore impeding economic development. The dependency theory, in contrast, has left limited marks on the UN DDs, perhaps because of the influence of developed donor countries in their conception. ${ }^{60}$

\section{B. The rise of the human development approach since the 1990s}

By the end of 1970s, the continued stagflation in developed countries affected their ability and willingness as donors while developing countries were facing the debt crisis. The dependency theory lost its influence along with the demands for the establishment of a NIEO. The 'lost decade' of 1980 was essentially the outcome of the 'neo-liberal counter-revolution', ${ }^{61}$ anchored also in the Bretton Woods institutions. This ideological turnaround stemming from the criticism to dirigisme and the distortions created by "irrational government interventions", 62 led to the decline of the development discourse and the rise of the globalization discourse. ${ }^{63}$ The

\footnotetext{
56 Ibid., para. 156.

57 lbid., para. 159.

58 Ibid., paras. 162-168.

59 Cf. Ziai, Development Discourse, 50

60 Other UN programs, however, focused solely on inward-looking development and collective reliance [Ratsimbaharison, The Failure of the United Nations Development Programs, 60].

61 Cf. Toye, Dilemmas, 22-44.

62 Lal, The Poverty of 'Development Economics', 134, 137.

${ }^{63}$ Ziai, Development Discourse, 118.
} 
economic situation of developing countries along with the World Bank/IMF structural adjustment programs led to the neglect of social and human dimensions of development. The modernization paradigm continued to dominate but now emphasized self-generated innovation and knowledge combined with the promotion of liberal political values. ${ }^{64}$ Amidst criticism for its policies, the World Bank complemented its recipe of market liberalization with good governance ${ }^{65}$ and subsequently embraced the goal of poverty eradication, ${ }^{66}$ thus introducing the human development dimension into the neo-liberal agenda. The UN was also instrumental in shifting the focus from macroeconomic goals to the human dimension of development ${ }^{67}$ and subsequently to sustainable development. ${ }^{68}$

Embracing the globalization discourse, the Strategy for the Fourth DD (1990) invited the countries to adopt policies "to facilitate open exchange and flexible responses to the changing world economy". ${ }^{69}$ Its "principal aim" was "a decade of accelerated development ... and strengthened international co-operation". Its chapter on goals and objectives focused on the "improvement in the human condition in developing countires", the "reduction of the gap between the rich and poor countries" and, echoing the sustainable development approach, on finding ways "for the world community to meet its needs without degrading the environment". Departing from the modernization paradigm, the resolution included "important social and political objectives": "the participation ... in economic and political life", the "protection of cultural identities" and the assurance of "the necessary means of survival' to everyone. It mentioned also the "respect of human rights, as well as social and economic rights, and of system of justice that protect all citizens". Recognizing the inter-dependence between institutions and economic development, it invited countries "to build the foundation on which development rests: technical and managerial skills, industrial and agricultural capability and effective government services", on the grounds that "[h]uman resources development entrepreneurship and innovation, and the energetic application of science and technology, in a context of political freedom, respect for human rights, justice and equity, are all essential and relevant do growth and development'. For the achievement of these objectives, it introduced six interrelated goals which, with the exception of the "development process that is

\footnotetext{
64 Stokke, "The Changing International and Conceptual Environments", 60, 64; Stokke, The UN and Development, 316-321; Cf. Jolly, "The UN Development”, 54-55; Abrahamsen, Disciplining Democracy.

65 Hout, "Development and Governance", 44.

66 Hulme, The Millennium Development Goals, 8; Jolly, “The UN Development”, 66-69.

67 Stokke, The UN and Development, 321-325, passim.

68 UN, Development and International Co-operation: Environment, Annex: Our Common Future; Cf. UN, The Future we Want.

69 UN, International Development Strategy for the Fourth Development Decade, para. 11.
} 
responsive to social needs", focused on economic development ${ }^{70}$ and referred to targets already set in various parts of the UN system. ${ }^{71}$

Its chapter on policy measures contained two separate sections. The first was dedicated to the "reactivation of the economy" - a reasonable goal after the 'lost decade' - placing the emphasis on economic development. ${ }^{72}$ The second, entitled "priority aspects of development", focused exclusively on social welfare in developing countries. It was thus recognized that social - or human - and economic development were of equal importance, the two sides of one and the same coin. The resolution admitted explicitly the failure of economic growth to ensure "that its benefits will be equitably distributed or that the physical environment will be protected and improved" and claimed that "if poverty persists or increases and there is neglect of the human condition, political and social strains will grow and endanger stability ... if environmental damage and degradation increase, the naturel resource base of developing countries and the welfare of populations will be harmed and progress in development itself will become unsustainable". ${ }^{73}$ According to this new argument, the improvement of the conditions of life in developing countries was necessary in order to ensure stability and maintain the present level of development - and security - in developed and developing countries alike. However, the recommended policies included, again, mainly measures promoting economic development, the development of human resources and the control of population. Measures aiming at the improvement of the conditions of life included the eradication of poverty and hunger, institutional development, locus classicus of the human development approach, with particular focus on education and health as well as the protection of the environment. ${ }^{74}$

The Millennium Declaration (2000) committed nations to a new global partnership to reduce extreme poverty and set out a series of time-bound targets. This resolution enumerated a number of fundamental principles necessary in international relations of the $21^{\text {st }}$ century, including the "responsibility for managing worldwide economic and social development" ${ }^{75}$ The list of areas of collaboration included "development and poverty eradication"76 while references to economic development were absent. The Roadmap, drafted by the Secretary General in order to specify the objectives of the Declaration, introduced the Millennium Development Goals (MDGs), focusing on poverty, education, gender equality health, and environmental

\footnotetext{
70 Ibid., paras. 13-15.

71 lbid., para. 18.

72 Ibid., paras. 21-77.

73 Ibid., para. 78.

74 Ibid., paras. 71-97.

75 UN Millennium Declaration, para. 6.

76 Ibid., paras. 11-28.
} 
sustainability. The Roadmap set also special quantitative targets for each of the goals accompanied by indicators for measuring performance.

The chapters of the Declaration and the Roadmap on development and poverty eradication subscribed to the human development approach. Ziai rightly observes that their references to development were connected to references to poverty eradication as a common goal and, on occasions, were used synonymously. ${ }^{77}$ References to economic development were limited and always attached to social development ${ }^{78}$ while no goal referred exclusively to economic development. In contrast, there were numerous references to economic growth and a chain of equivalences was established between development, poverty eradication and economic growth. ${ }^{79}$ Following the modernization paradigm, the Roadmap suggested that "[i]n order to significantly reduce poverty and promote development it is essential to achieve sustained and broad-based economic growth". ${ }^{80}$ In contrast, elsewhere this causality was reversed. The Roadmap explained, for example, that the chapter on development and poverty eradication "focuses on sustainable development through poverty eradication". ${ }^{81}$

The UN begun to re-design its development policy even before the completion of the millennium, this time focusing on sustainable development. ${ }^{82}$ After the initial decision in Rio+20 Summit (2012), ${ }^{83}$ the Addis Ababa Action Agenda (2015) introduced the general principles of a global framework for financing development, particular areas of action as well as mechanisms for the collection of data and monitoring performance. The aim of the governments is now "to end poverty and hunger, and to achieve sustainable development in its three dimensions through promoting inclusive economic growth, protecting the environment, and promoting social inclusion". ${ }^{4}$ The Agenda recommends the adoption of combined actions to cover important gaps, amongst others, in the areas of social protection and essential public services, hunger and malnutrition, protection of ecosystems, peaceful and inclusive societies, improvement of infrastructure, full and productive employment as well as inclusive and sustainable industrialization. ${ }^{85}$ The 2030 Agenda for Sustainable Development (2015) builds upon the results of the MDGs but has a wider content in an attempt "to complete

\footnotetext{
${ }_{77}$ Ziai, Development Discourse, 158.

78 UN Millennium Declaration, paras. 6, 30.

79 Ziai, Development Discourse, 158.

$80 \mathrm{UN}$, Road Map towards the Implementation of the Millennium Declaration, para. 80.

81 Ibid., 2-3; Cf. Ziai, Development Discourse, 158.

82 Ziai, Development Discourse, 194

${ }^{83}$ Report of the UN Conference on Sustainable Development; Cf. Sachs, The Age of Sustainable Development, 481-484.

${ }^{84}$ UN, Addis Ababa Action Agenda, Annex, para. 1.

85 Ibid., paras. 11-19.
} 
what these did not achieve". It introduces 17 Sustainable Development Goals (SDGs), "integrated and indivisible and balanc[ing] the three dimensions of sustainable development: the economic, social and environmental." 86 These are in fact an improved or more ambitious ${ }^{87}$ version of the MDGs. ${ }^{88}$ Yet, unlike the latter, the Agenda promotes also economic growth, in particular, the increase of the GDP, domestic technology development, research and innovation, industrial diversification and inclusive and sustainable industrialization. ${ }^{89}$

Without abandoning the goal of economic growth, the Strategy for the Fourth DD embraced the human development approach expanding the existing and introducing new welfare goals. This shift from economic to human development culminated in the adoption the MDGs. Yet, apart from neglecting economic development ${ }^{90}$ and adopting a one-sided and hence fragmentary approach to the problem of development, ${ }^{91}$ as Stokke explains, the Millennium Declaration focused on "results to be attained within set time horizons involving a broad set of vague policies and reforms". Despite their coherence, ${ }^{92}$ the MDGs were fragmentary since they failed to address the social, cultural and political interrelation of the development process. ${ }^{93}$ They aimed to achieve average improvements, failed to adequately cope with the problem of inequality ${ }^{94}$ and on occasions fell short of previous targets. ${ }^{95}$

Building on the experience of the UNDP human development indicators (1990) and the OECD Goals of International Development (1996), the UN introduced quantitative targets and indicators on human development. This method simplifies problems, focusing on what is recognisable and countable, neglecting the essential but complex and multidimensional. ${ }^{96}$ The introduction of separate targets encourages the selective approach of the goals ${ }^{97}$ while the achievement of the targets does not explain whether the goals were met due to measures taken in the context of the MDGs' effort or due to other factors. ${ }^{98}$ Through the idea of

\footnotetext{
86 UN, Transforming our World, Annex \& para. 18.

87 See, A New Global Partnership: Eradicate Poverty and Transform Economies through Sustainable Development, The Report of the High-Level Panel of Eminent Persons on the Post-2015 Development Agenda, cited in Ziai, Development Discourse, 198.

88 Brenner, "Global Goal-Setting”, 183.

89 UN, Transforming our World, Goal 9, para. 9.2, 9.b.

90 Jolly, "The UN and Development Policies", 6.

91 Turshen, "A global partnership", 347.

92 Hulme, The Making of the Millennium Development Goals, 2.

93 Stokke, The UN and Development, 478; Cf. Brenner, "Global Goal-Setting", 173.

94 Gwatkin, Who Would Gain Most, 21.

95 E.g., Pogge, "The First United Nations Millennium Development Goal”, 378.

96 Black \& White, "Millennium Development Goals", 16.

97 Brenner, "Global Goal-Setting", 171-172.

98 E.g., UN, The Millennium Development Goals Report 2007, 7; Friedman, Causal Inference.
} 
sustainable development, the Agenda 2030 adopts a more balanced approach to development. The SDGs re-introduce the goal of economic growth of the modernization paradigm, now tempered by elements of the human development approach. Yet, the Agenda retains the fragmentary goals and the separate quantitative targets' method of the MDGs. As a result, the SDGs suffer from the same drawbacks.

\section{The persistence on the technical approach to development}

Despite their differences, the UN resolutions follow an identical pattern to achieve the objectives of economic and social development alike. Establishing a general policy framework, they implicitly acknowledge the existence of a universal process and hence of a single model for development, ${ }^{99}$ despite claims to the contrary of the human development approach. They see countries as homogenous groups, developed vs developing, ${ }^{100}$ neglecting their individual characteristics and particularities, even though some resolutions introduce measures tailored to the needs of specific groups of developing countries. ${ }^{101}$ With its references to all countries, the Agenda 2030 adopts the universalistic approach of the globalization discourse but the dichotomy remains since developed countries are the ones to provide the funds and developing the ones to realize the goals. ${ }^{102}$

Furthermore, the resolutions espouse a mechanistic approach to the achievement of development. They uniformly adopt the input/output model, defining inputs and outcomes to be attained accompanied by relevant quantitative targets in relation to the financial resources to be dedicated to development as well as the particular goals of economic or human development. ${ }^{103}$ Even though they often mention "the people", usually as beneficiaries and rarely as actors ${ }^{104}$ of the development effort, all resolutions provide for goals and objectives to be achieved through State intervention, and recommend policies and measures to be introduced into developing countries' national plans for development in accordance with the teachings of the modernization paradigm.

\section{A. State planning and intervention}

The Program for the First DD focused on State policies for development, promoting State intervention in national economy in order to achieve primarily economic growth. By way of

\footnotetext{
99 Ziai, Development Discourse, 95.

100 E.g., UN, International Development Strategy for the Second Development Decade, para. 14; International Development Strategy for the Third Development Decade, para. 2; Road Map towards the Implementation of the Millennium Declaration, para. 203; Ziai, Development Discourse, 167-168.

101 E.g., UN, International Development Strategy for the Third Development Decade, paras. 136-155.

102 Ziai, Development Discourse, 197-198.

103 Stokke, The UN and Development, 478.

104 E.g., UN, International Development Strategy for the Second Development Decade, para. 19.
} 
illustration, countries were invited to "pursue policies designed to enable the less developed counties ... to sell more of their products at stable and remunerative prices in expanding markets, and thus to finance ... their own economic development"105 as well as "to adopt measures which will stimulate the flow of private investment capital for economic development'. ${ }^{106}$ The resolution stressed, albeit implicitly, the importance of central planning. ${ }^{107}$ It invited the countries to take measures in order "to attain in each underdeveloped country substantial increase in the rate of growth", but assigned to developing countries the task of setting their own targets ${ }^{108}$ while providing for "measures for assisting" them, "at their request, to establish well-conceived and integrated country plans". Recommendations on the content of such plans included land reform, commonly promoted since the mid-1940s for political, ideological and economic reasons ${ }^{109}$ and the mobilization and utilization of "resources offered by foreign sources ... for progress towards self-sustained growth". ${ }^{110}$ Along with planning and as a necessary complement thereof, the resolution encouraged the "review of facilities for the collection, collation, analysis and dissemination of statistical and other information required for charting economic and social development and for providing a constant measurement of progress objectives of this Decade". ${ }^{111}$

Following the same pattern, the Strategy for the Second DD invited developing countries to "adopt vigorous measures for a fuller mobilization of the whole range of their domestic financial resources", "pursue sound fiscal and monetary policies ... remove institutional obstacles through the adoption of appropriate legislative and administrative reforms"112 and "adopt appropriate measures for inviting, stimulating and making effective use of foreign private capital'. ${ }^{113}$ Special attention was given, once again, to planning. Reiterating the proclamation of the Charter of Algiers (1967) that "[t]he primary responsibility for the development of developing countries rests upon themselves", ${ }^{114}$ the resolution invited every developing country to "set its own target for growth in the light of its own circumstances", 115 in other words, to adopt national development plans. Developing countries were also invited to "establish or

\footnotetext{
105 UN Development Decade: A Programme for International Economic Co-operation (I), para. 2(a). 
strengthen their planning mechanisms, including statistical services, for formulating and implementing their national development plans". ${ }^{116}$ Finally, even though States were assigned the tasks of choice and application of the measures, the resolution mentioned also, for the first time, the mobilization of public opinion, albeit limited to the "support of the objectives and policies of the Decade". 117

The Strategy for the Third DD relied again on State intervention. Governments were invited to "actively pursue policies with a view to encouraging continued reallocation of resources and encouraging domestic factors of production to move from internationally less competitive to more viable lines of production or into other sectors of the economy". ${ }^{118}$ The resolution referred again to the responsibility of developing countries for their development ${ }^{119}$ and contained numerous references to central planning. Amongst others, it mentioned the "need for the adoption of adequate and appropriate policies, to be defined by each country within the framework of its development plans and priorities, for movement towards the realisation of this ultimate goal of development"120 while recommending the formulation of "[n]ational development plans ... on the basis of a unified approach to economic and social development". ${ }^{121}$ Finally, the resolution maintained the reference to the mobilization of public opinion. ${ }^{122}$

Despite the criticism against dirigisme, the rise of the globalization discourse and the subsequent shift from the modernization paradigm to the human development approach, the references to State planning remained. The Strategy for the Fourth DD recognized that "[t]he role of the public sector in the development process is essential', ${ }^{123}$ and, in particular, that "effective national policies have a critical role to play in achieving sustained, non-inflationary economic growth in all countries". ${ }^{24}$ "[B] ureaucratic inefficiencies" were held liable for placing "[i]mpediments to progress". ${ }^{125}$ However, references to central plaining were limited. The resolution accepted the responsibility of each country "for its own economic policies for

\footnotetext{
116 lbid., para. 78.

117 lbid., para. 84.

118 UN, International Development Strategy for the Third Development Decade, para. 73.

119 lbid., para. 9.

120 lbid., para. 8.

121 lbid., para. 42.

122 lbid., para. 14.

123 UN, International Development Strategy for the Fourth Development Decade, para. 25.

124 lbid., para. 11.

125 lbid., para. 25.
} 
development" and developing countries were invited "to set themselves ambitious targets". ${ }^{126}$ The sole reference to planning was introduced in relation to the enhancement of "scientific and technological capabilities" of developing countries. ${ }^{127}$ By then, it had become common knowledge that State intervention alone was not sufficient to achieve development in the modern globalized economic environment. What was needed was collaboration, not only with other countries but also with other stakeholders. The resolution referred therefore to the mobilization of "all the lattent energies and impulses for development within developing countries" with an explicit mention of the private sector and the people. ${ }^{128}$

Similarly, both the Millennium Declaration and the Roadmap relied on State measures and intervention for the achievement of the MDGs. The Roadmap invited the countries to make the MDGs "national goals", and "ensure that poverty reduction strategies increase the focus on the poorest and most vulnerable through an appropriate choice of economic and social policies". ${ }^{129}$ Brown explains that past experience demonstrated the need for the adoption of the goals by the States, in particular, their adaptation to the particular national circumstances and their integration into the mid-term national goals and strategies. ${ }^{130}$ Planning however was never mentioned in the Declaration and was only rarely mentioned in the Roadmap. This was not because of some sudden aversion to planning. As the Roadmap explained, "plans of action needed for reaching these targets have, for the most part, already been developed and formally adopted". ${ }^{131}$ It is therefore far from a change of policy. According to Ziai, "[t]he perspective of planning, of deliberate interventions in the economy with the aim of achieving improvements, is also at the basis of the MDGs themselves". ${ }^{132}$ In reality, interventions were hardly limited to the economy. For, the achievement of the MDGs inevitably involved interventions also in "societies, spaces and individuals". ${ }^{133}$ Despite the pre-eminent role of the State in the achievement of the MDGs, the Roadmap added the need "to broaden partnerships between all stakeholders, such as civil society and the private sector"134 and included an explicit invitation to the pharmaceutical industry. ${ }^{135}$ Brown confirms that forging partnerships

\footnotetext{
126 lbid., para. 13, 15.

127 lbid., para. 57.

128 lbid., para. 25.

129 UN, Road Map towards the Implementation of the Millennium Declaration, paras. 81-82.

130 Brown, "Foreword", xviii.

131 UN, Road Map towards the Implementation of the Millennium Declaration, para. 6.

132 Ziai, Development Discourse, 157.

133 Gabay, "The Millennium Development Goals”, 1256.

134 UN, Road Map towards the Implementation of the Millennium Declaration, para. 82; Cf. UN Millennium Declaration, para. 20.

135 UN, Road Map towards the Implementation of the Millennium Declaration, 23; Cf. UN Millennium Declaration, para. 20.
} 
"of governments of poor and rich countries, of private corporations and foundations, of multilateral agencies, of civil society organisations and, most importantly, of the poor themselves" was central to the success of the goals. ${ }^{136}$

Finally, the Agenda 2030 reiterates the responsibility of each country "for its own economic and social development"137 and the role of governments to "decide how these aspirational and global targets should be incorporated in national planning processes, policies and strategies". ${ }^{138}$ State panning along with State intervention constitute again the core elements of the Agenda. However, the Agenda places some limits on the pre-eminence of the State. Adopting a top-down approach, it explains that "the role of national policies and development strategies cannot be overemphasized. We will respect each country's policy space and leadership to implement policies for poverty eradication and sustainable development, while remaining consistent with relevant international rules and commitments". ${ }^{139}$ In contrast, the role of other stakeholders is, again, limited to the "support of implementation of all the goals and targets". ${ }^{140}$

States remain the great protagonists of the UN effort on development. Establishing only a general policy framework, the resolutions place on developing countries the burden to specify their development measures. Interestingly enough, instead of "[t]he right of every country to adopt the economic and social system that it deems the most appropriate for its own development', proclaimed in the context of the NIEO, ${ }^{141}$ the resolutions introduce a responsibility for development, a duty of developing countries to ensure their own development, thus offering an excuse to developed countries for the ever-widening gap between North and South. A different explanation advanced by Ziai for this involvement of developing countries may be the "reaction to the critique of development policy as a top-down, authoritarian enterprise" that led to "the transformation of the development discourse according to the new concepts of participation, empowerment and ownership" which, nevertheless, cannot hide the reality of the asymmetrical donor/recipient relationship. ${ }^{142}$

Attributing a central role to the State, the resolutions subscribe to a fundamental premise of the neo-Keynesian theories that inspired the modernization paradigm. Development is considered, to quote Ferguson, "as something that only comes through governmental action,

\footnotetext{
${ }^{136}$ Brown, "Foreword", xviii.

137 UN, Transforming our World, paras. 41, 63.

138 lbid., para. 55.

139 lbid., para. 63.

140 lbid., para. 60.

141 UN, Declaration on the Establishment of a New International Economic Order, para. 4(d).

142 Ziai, Development Discourse, 92-93.
} 
the lack of 'development', by definition is the result of government neglect'. The State is seen as an impartial instrument for implementing plans and the government as a neutral, impartial and effective machine for providing services and engineering growth while failures of bureaucracy are attributed to poor organization and lack of training. This approach, neglects "the political character of the State and its class basis, the uses of official positions and State power by the bureaucratic elite and other individuals, cliques and factions, and the advantages to them of bureaucratic 'inefficiency' and corruption". ${ }^{143}$ This unrestrained reliance on the State may overestimate the capacity of its apparatus or the willingness of the local elites to design and implement the necessary policies and measures in order to fulfil the duty of development.

The government itself is never questioned on the assumption that its actions for the achievement of development, including the use of violence, are benign since development is viewed as a positive goal ${ }^{144}$ while authoritarian regimes may even be more suitable to play the role assigned to the State. ${ }^{145}$ Other centers of power are ignored ${ }^{146}$ or their role is limited to the support of the implementation of State measures. The role of business is also neglected, presumably on the correct assumption that the private sector cannot solve many critical problems of human development, ${ }^{147}$ even though business is expected to contribute to the implementation of development policies. Interestingly enough, the same applies to the local population of developing countries, "the poor themselves", despite the intervention in their lives that the implementation of development programs may involve and which they may disapprove. ${ }^{148}$

\section{B. The input/output model}

The Program for the First DD introduced the input/output model to the UN development programs. The resolution defined the provenance of the financial resources for development, namely, trade, domestic savings and foreign investments. ${ }^{149}$ However, other than the general invitation to increase the flow of development resources ${ }^{150}$ and the reference to resources to be released by disarmament, ${ }^{151}$ the resolution made no mention of ODA. Other resolutions

\footnotetext{
143 Ferguson, "The Anti-Politics Machine", 178.

144 Ziai, Development Discourse, 178.

145 See, Nandy, Development and Violence, 8-15; Stokke, "The Changing International and Conceptual Environments", 66.

146 Ziai, Development Discourse, 159-160; Ferguson, "The Anti-Politics Machine", 178.

147 See, Sachs, The Age of Sustainable Development, 498-499.

148 For an interesting discussion of the authoritarian implication of development and the problem of legitimization of development interventions, see, Ziai, Development Discourse, 62-63.

149 UN Development Decade: A Programme for International Economic Co-operation (I), paras. 3-4, passim.

150 Ibid., para. 2(c).

151 lbid., para. 4(i).
} 
referred to an increase of the annual flow of international aid and capitals to reach the $1 \%$ of the aggregate national incomes of developed countries ${ }^{152}$ and invited countries to review their contributions in support of UN programs so that their combined budgets in the year 1962 reach the target of $\$ 150$ million. ${ }^{153}$ Finally, the resolution contained a single quantitative target, "a minimum annual rate of growth of aggregate national income of 5 per cent at the end of the Decade". ${ }^{154}$

The same technical approach to development is overtly followed by the Strategy for the Second DD. For instance, the resolution explained that "[a]n average annual rate of growth of at least 6 per cent in the gross product of developing countries during the Decade will imply an average expansion of a. 4 per cent in agricultural output; b. 8 per cent in manufacturing output'. ${ }^{155}$ The financial resources for development mentioned included trade, domestic savings, foreign investment and ODA. Developed countries were invited to contribute a minimum net amount of $1 \%$ of their gross national product and to progressively increase their aid to reach a minimum of $0.7 \%$ of their gross national product. ${ }^{156}$ Output targets included the optimistic $6 \%$ for the average annual rate of growth of the gross product and of $3.5 \%$ for the average annual rate of growth of the gross per head product of developing countries. ${ }^{157}$

Similarly, the Strategy for the Third DD explained, this time in hypothetical terms, that "[i]f the average rate of growth of population in the developing countries were to remain at about 2.5 per cent, an average increase of 7 per cent in gross domestic product would lead to an annual increase of about 4.5 per cent in per capita gross domestic product'. ${ }^{158}$ Stressing the need for an increase of ODA, it invited developed countries to exceed the agreed target of $0.7 \%$ of their gross national product ${ }^{159}$ and set a number of general output targets, the optimistic $7 \%$ for the average annual rate of growth in the gross product ${ }^{160}$ and $4.5 \%$ for the average annual rate of growth of the gross per head product in developing countries as well as a number of

\footnotetext{
152 UN, Reaffirmation of GA Resolution 1522 (XV), para. 1.

153 UN Development Decade: A Programme for International Economic Co-operation (II), para. 1

154 lbid.

155 UN, International Development Strategy for the Second Development Decade, para. 16.

156 Ibid., paras. $42-43$

157 Ibid., paras. 13-14.

158 UN, International Development Strategy for the Third Development Decade, para. 21.

159 lbid., para. 98.

160 lbid., para. 20.
} 
targets for commodities trade and investment ${ }^{161}$ and for agricultural and industrial output in developing countries. ${ }^{162}$

Despite the change in paradigm, the subsequent resolutions retained the same pattern. The Strategy for the Fourth DD referred to domestic savings while admitting that local resources were insufficient to meet the needs of development and external resources were limited. ${ }^{163}$ Hence, the resolution recommended the reduction of the burden of debt-service payments and the provision of ODA, inviting developed countries to contribute a minimum of $0.7 \%$ of their GDP, while stressing the need for commercial loans, private investments and contribution of multinational financing institutions. ${ }^{164}$ Unlike previous resolutions, it set no new quantitative targets for outputs but referred instead to targets already adopted "in various parts of the United Nations system". ${ }^{165}$

The Millennium Declaration and the Roadmap adopted the same technical approach to development. ${ }^{166}$ Hulme observes that human development and results-based management where amongst the ideas that have influenced the final content of the MDGs. ${ }^{167}$ The Roadmap defined the financial resources to be used for the achievement of the MDGs. Funding was, again, expected to come from domestic resources, foreign investment and ODA. Developed countries were invited to honour their engagement of $0.7 \%$ of their GDP. ${ }^{168}$ Special targets were also set for each of the MDGs along with indicators for measuring performance against the baseline year 1990. ${ }^{169}$ Similarly, the Agenda 2030 defines the resources to be used for the achievement of the SDGs, mainly domestic public resources and international public finance, including ODA. ${ }^{170}$ The resolution repeats the target of $0.7 \%$ of developed countries' GDP, adds a target of 0.15 to $0.20 \%$ for the least developed countries ${ }^{171}$ and sets 169 output targets for the SDGs accompanied by relevant indicators for measuring performance. ${ }^{172}$

\footnotetext{
161 lbid., paras. 22-23.

162 lbid., paras. 28-29.

163 UN, International Development Strategy for the Fourth Development Decade, paras. 33-36.

164 Ibid., paras. 38-45.

165 lbid., para. 18.

166 Ziai, Development Discourse, 159-160.

167 Hulme, The Making of the Millennium Development Goals, 1.

168 UN, Road Map towards the Implementation of the Millennium Declaration, paras. 131-138.

169 Ibid., paras. 83-163 \& Annex; Cf. Stokke, The UN and Development, 445-457.

170 Cf. Sachs, The Age of Sustainable Development, 496-502.

171 UN, Transforming our World, para. 43.

172 lbid., para. 55.
} 
The input/output model involves the introduction of certain financial resources in order to achieve certain quantitative targets of economic and social development. Defining development in terms of ratios between population growth, GDP' increase and agricultural and manufacturing output, the Strategies for the Second and Third DD overtly adhere to this model. The problem of development, as Ziai observes, "seems to arise from the lack of resources" necessary to overcome the poverty trap and introduce self-sustaining growth, "a challenge in terms of mobilising sufficient resources". It is therefore assumed "that social problems can be solved with technocratic solutions". ${ }^{173}$ Sachs defends "goal-based development" on account of the role of goals for social mobilization, peer pressure to governments, mobilization of epistemic communities, knowledge networks and stakeholder networks. ${ }^{174}$ In reality, as Browne explains, "[t]here is certainly no automatic 'hydraulic' approach of aid in, development out". The absence of an automatic mechanism for generating development through introduction of financial resources was illustrated in the failure of ODA to deliver economic and, even less, human development, ${ }^{175}$ attributed to a number of factors, amongst others, to incentives and information' problems of donors and recipients alike. ${ }^{176}$

The reference to relations of cause and effect along with the quantification of input and output offer a scientific - or pseudoscientific - justification of the recommended policy measures. Implicitly subscribing to the linear model of scientific expertise where science dictates policy, ${ }^{177}$ the resolutions appear to rely on some 'value-free' scientific 'truth' that legitimizes their recommendations while concealing the political debate behind the choice between alternative development paradigms. As Hulme explains, the MGDs "are commonly presented as deriving from technical and empirical analysis" thus concealing that they are the product of intense political negotiations, ${ }^{178}$ between developed donor and developing recipient countries. ${ }^{179}$ Through the input/output model, according to Ziai, "[a]chieving development, meeting the MDG targets and reducing global poverty are presented not as political, but as technical problems". Apart from neglecting political obstacles, social conflicts or parties whose interests could be harmed, through the use of quantitative targets, "[d]evelopment seems as a consensual, nonconflictive goal to be achieved by technical processes to which no one can object'. In other words, the resolutions adopt a technical and, therefore, depoliticized approach

\footnotetext{
173 Ziai, Development Discourse, 61, 159, 170.

174 Sachs, The Age of Sustainable Development, 490-491.

175 Browne, "A Changing World", 1856.

176 E.g., Williamson, "Exploring the failure of foreign aid", 17-33.

177 Beck, "Moving beyond the linear model of expertise?", 298.

178 Hulme, The Millennium Development Goals, 47.

179 E.g. Flory, "The International Development Strategy", 70-72.
} 
to the problem of poverty and development. ${ }^{180}$ From that perspective, the UN approach is similar to the technocratic approach of the World Bank. ${ }^{181}$ This resemblance may be attributed to the role of developed donor countries, in particular the United States, in shaping UN development policies, exemplified by the influence of the OECD in the definition of the MDGs. ${ }^{182}$ This depoliticized approach serves to justify State intervention, including the use of violence wherever necessary for the achievement of the goals and objectives of the resolutions.

\section{Conclusion}

Differences in the goals, objectives, targets and policy measures of the successive resolutions on the UN DDs reveal an evolution of the UN development policies. For, even though all resolutions refer to both economic and social development and do not always define the relation of priority, the change of focus in their narratives reveals a gradual shift from the modernization paradigm to the human development approach. Despite this evolution, all relevant resolutions follow an identical pattern for the achievement of development. They all define inputs and outputs accompanied by relevant quantitative targets in relation to financial resources to be dedicated in order to achieve particular goals of economic or human development and all rely on State intervention, recommending policies and measures to be introduced into developing countries' specific plans for development.

Concealing that the DDs are the product of intense political negotiations and that the achievement of their targets is subject to political obstacles, social conflicts and adverse interests, this depoliticized approach not only simplifies the problem of development but also justifies the underlying development paradigm, the recommended policy measures and, consequently, the relevant interventions of the State in the economy and society. And since the policies and the underlying development paradigm themselves are not questionable, any failure to achieve the quantitative targets is attributed to either the lack of resources or the misapplication of the recommended policies. Governments are thus the sole responsible for the failure of the programs, for failing to contribute what they have promised or to apply what they were recommended.

But if the input/output model, introduced in order to promote economic development could be justified for the identity of input and output, economic resources to achieve economic targets, one has to wonder whether this model is still appropriate for the achievement of the multidimensional development advocated by the human development approach. Similar

\footnotetext{
180 Ziai, Development Discourse, 61, 159-160, 224-225, passim.

181 Fatouros, "On the Hegemonic Role", 26.

182 Hulme, The Millennium Development Goals, 12-25.
} 
considerations apply in relation to the central role of the State in the light of the requirement of mobilization of all stakeholders of the society for the promotion of human development. If that is the case, then using the old tools for the achievement of new goals may be due to a lack of imagination or indicate a reluctance of the UN - or of the developed donor countries to abandon the modernization paradigm. The re-introduction of economic development in the Agenda 2030 may point to the second explanation.

\section{Bibliography}

Abrahamsen, R., Disciplining Democracy: Development Discourses and Good Governance in Africa. Zed Books, 2000.

Acemoglu, D. \& Robinson, J.A., Why Nations Fail: The Origins of Power, Prosperity, and Poverty. Profile Books, 2012.

Beck, S., "Moving beyond the linear model of expertise? IPCC and the test of adaptation", Regional Environmental Change, no. 11 (2011): 297-306.

Black, R. \& White, H., "Millennium Development Goals: A Drop in the Ocean?". In Targeting Development: Critical Perspectives on the Millennium Development Goals, edited by Black, R. \& White, H., 1-24. Routledge, 2004.

Blömström, M. \& Hettne, B., Development Theory in Transition: The Dependency Debate and Beyond: Third World Responses. Zed Books Ltd., 1984.

Brenner, R., "Global Goal-Setting: How the Current Development Goal Model Undermines International Development Law", Michigan State International Law Review, no. 24 (2015): 145-209.

Brown, M.M., "Foreword". In Targeting Development: Critical Perspectives on the Millennium Development Goals, edited by Black, R. \& White, H., xviii-xix. Routledge, 2004.

Browne, S.F., "United Nations Development System in Asia", Criterion, no. 7 (2012), http://www.criterion-quarterly.com/united-nations-development-system-in-asia. Accessed 01.03.2016.

Browne, S., "A Changing World: Is the UN Development System Ready?", Third World Quarterly, no. 35 (2014): 1845-1859.

Cornia, G.A., Jolly, R. \& Stewart, F., Adjustment with a Human Face: Protecting the vulnerable and promoting growth. Clarendon Press, 1987.

Dunning, J.H., "Towards a New Paradigm of Development: Implications for the Determinants of International Business", Transnational Corporations, no. 15 (2006): 173-227.

Fatouros, A.A., "On the Hegemonic Role of the International Functional Organization", German Yearbook of International Law, no. 23 (1980): 9-36.

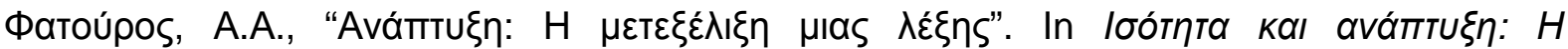

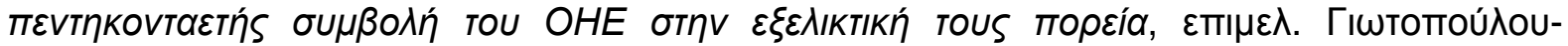

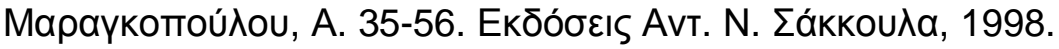

Ferguson, J., "The Anti-Politics Machine: Development and the Bureaucratic Power in Lesotho", The Ecologist, no. 24 (1994): 176-181.

Flory, M., "The International Development Strategy for the Third United Nations Development Decade", Journal of African Law, no. 26 (1982): 68-73.

Friedman, H.S., Causal Inference and the Millennium Development Goals (MDGs): Assessing Whether There Was an Acceleration in MDG Development Indicators Following the MDG 
Declaration, MPRA Paper no. 48793/2013. https://mpra.ub.unimuenchen.de/48793/1/MPRA_paper_48793.pdf. Accessed 01.03.2016.

Gabay, C., "The Millennium Development Goals and Ambitious Developmental Engineering", Third World Quarterly, no. 33 (2012): 1249-1265.

Gwatkin, D.R., Who Would Gain Most from Efforts to Reach the Millennium Development Goals for Health?: An Inquiry into the Possibility of Progress that Fails to Reach the Poor. HMP Discussion Paper. IBRD/The World Bank, 2002.

Hettne, B., Development Theory and the Three Worlds. Longman, 1995.

Hobsbawm, E., Age of Extremes: The Short Twentieth Century 1914-1991. Abacus, 1994.

Hout, W., "Development and Governance: An Uneasy Relationship". In Governance and the Depoliticisation of Development, edited by Hout, W. \& Robison, R., 38-55. Routledge, 2009.

Hulme, D., The Making of the Millennium Development Goals: Human Development Meets Results-based Management in an Imperfect World. Brooks World Poverty Institute Working Paper 16/2007.

Hulme, D., The Millennium Development Goals (MDGs): A Short History of the World's Biggest Promise. Brooks World Poverty Institute Working Paper 100/2009.

Jolly, R., "The UN Development Thinking and Practice", Forum for Development Studies, no. 32 (2005): 49-73.

Jolly, R., "The UN and Development Policies", UN Intellectual History Project, Briefing Note no. $\quad 7 / 2010$, http://www.unhistory.org/briefing/7UNandDevStrategies.pdf. Accessed 01.03.2016.

Kotsching, W. M., "The United Nations as an Instrument of Economic and Social Development", International Organization, no. 22 (1968): 16-43.

Lal, D., The Poverty of 'Development Economics'. The Institute of Economic Affairs, 2002.

Leys, C., "The Rise and Fall of Development Theory." In The Anthropology of Development and Globalization, edited by Edelman, M. \& Haugerud, A., 109-125. Blackwell, 2004.

Murphy, C.N., "Evolution of the UN Development System". In Post-2015 UN Development: Making Change Happen?, edited by Browne, S. \& Weiss, T.G., 35-54. Routledge, 2016.

Nandy, A., Development and Violence. Zenterum für Europäische Studien, Universität Trier, 1995.

Normand, R. \& Zaidi, S., Human Rights at the UN: The Political History of Universal Justice. Indiana University Press, 2008.

Pogge, Th., "The First United Nations Millennium Development Goal: A Cause for Celebration?", Journal of Human Development, no. 5 (2004): 377-397.

Ratsimbaharison, A.M. The Failure of the United Nations Development Programs for Africa. University Press of America 2003.

Rist, G., The History of Development from Western Origins to Global Faith. Zed Books, 2008.

Stokke, O., "The Changing International and Conceptual Environments of Development Cooperation". In Perspectives on European Development Co-operation: Policy and Performance of Individual Donor Countries and the EU, edited by Howbink, P. \& Stokke, O., 32-112. Routledge, 2005.

Stokke, O., The UN and Development: From Aid to Cooperation. Indiana University Press, 2009.

Sachs, J.D., The Age of Sustainable Development. Columbia University Press, 2015. 
Toye, J., Dilemmas of Development: Reflections on the Counter-Revolution in Development Economics. Blackwell, 1987.

Tucker, V., "The Myth of Development: A Critique of a Eurocentric Discourse". In Critical Development Theory: Contributions to a New Paradigm, edited by Munck, R. \& O'Hearn, D., 1-26. Zed Books Ltd., 1999.

Turshen, M., "A global partnership for development and other unfulfilled promises of the millennium project", Third World Quarterly, no. 35 (2014): 354-357.

Williamson, C.R., "Exploring the failure of foreign aid: The role of incentives and information", The Review of Austrian Economics, no. 23 (2010): 17-33.

Ziai, A., Development Discourse and Global History: From Colonialism to the Sustainable Development Goals. Routledge, 2016.

UN Development Decade: A Programme for International Economic Co-operation (I), GA Resolution 1710 (XVI) (19/12/1961).

UN, Reaffirmation of General Assembly Resolution 1522 (XV) on the Accelerated Flow of Capital and Technical Assistance to Developing Countries, GA Resolution 1711 (XVI) (19/12/1961).

UN, International Development Strategy for the Second United Nations Development Decade, GA Resolution 2626 (XV) (24/10/1970).

UN, Declaration on the Establishment of a New International Economic Order, GA Resolution 3201 (S-VI) (1/6/1974).

UN, International Development Strategy for the Third United Nations Development Decade, GA Resolution 35/56 (5/12/1980).

UN, Declaration on the Right to Development, GA Resolution A/RES/41/128 (4/12/1986).

UN, Development and International Co-operation: Environment, Report of the World Commission on Environment and Development. A/42/427 (04/08/1987).

UN, International Development Strategy for the Fourth United Nations Development Decade, GA Resolution A/RES/45/199 (21/12/1990).

UN, Millennium Declaration, GA Resolution A/RES/55/2 (18/12/2000).

UN, Road Map towards the Implementation of the United Nations Millennium Declaration: Report of the Secretary-General, A/56/326 (06/09/2001).

UN, The Millennium Development Goals Report 2007.

UN, The Future we Want, GA Resolution A/RES66/288 (27/07/2012).

UN, Report of the United Nations Conference on Sustainable Development, Rio de Janeiro, Brazil 20-22 June 2012, A/CONF.216/16.

UN, Addis Ababa Action Agenda of the Third International Conference on Financing for Development, GA Resolution A/RES/69/313 (27/07/2015).

UN, Transforming our World: The 2030 Agenda for Sustainable Development, GA Resolution A/RES/70/1 (25/09/2015). 
